\title{
Upaya Menangani Nyeri Dan Kecemasan Pada Lansia Yang Mengalami Hipertensi Di Masyarakat
}

\author{
N Sukesi*1, Wahyuningsih ${ }^{2}$ \\ 1,2Fakultas Keperawatan, Bisnis serta Teknologi, Universitas Widya Husada Semarang \\ *e-mail: nikensukesi2004@gmail.com ${ }^{1}$, wahyu198223@yahoo.com ${ }^{2}$
}

Nomor Handphone Untuk keperluan koordinasi : 081225668169

\begin{abstract}
Abstrak
Hipertensi adalah penyakit pembuluh darah yang mempunyai tekanan darah tinggi (sitolik 140 $\mathrm{mmHg}$ serta diastolik $90 \mathrm{mmHg}$ ) yang menetap. Gejala hipertensi ialah nyeri serta kekakuan otot. Hal ini yang menimbulkan lansia yang mengidap hipertensi mengalami permasalahan psikologis salah satunya kecemasan. Nyeri serta kecemasan bisa dilakukan dengan tindakan mandiri oleh lansia. Tujuan kegiatan ini lansia yang hipertensi diharapkan mampu melakukan relaksasi nafas dalam, relaksasi otot progresif serta yoga ringan supaya mengurangi nyeri serta kecemasan. Metode yang digunakan berupa penyuluhan, pelatihan dan demonstrasi. Hasil dari pengabdian ini dari 10 lansia mengalami peningkatan pengetahuan sebanyak 90\%. Lanisa yang mengikuti program ini sangat bersemangat dalam proses praktek dan pemberian materi. Hasil dari pretest lansia belum mengenali penanganan nyeri serta kecemasan sebaliknya hasil dari post test lansia mampu memahami dan mempraktikan secara benar. relaksasi nafas dalam, relaksasi otot progresif serta latihan gerakkan yoga ringan sebanyak 90\%. Latihan ini dapat dilaksanakan setiap hari untuk mengurangi tekanan darah, nyeri serta kecemasan.
\end{abstract}

Kata kunci: lansia, hipertensi, relaksasi nafas dalam, otot progresif, yoga

\begin{abstract}
Hypertension is a blood vessel disease that has persistent high blood pressure (systolic $140 \mathrm{mmHg}$ and diastolic $90 \mathrm{mmHg}$ ). Symptoms of hypertension are pain and muscle stiffness. This causes the elderly who suffer from hypertension to experience psychological problems, one of which is anxiety. Pain and anxiety can be done independently by the elderly. The purpose of this activity is that elderly people with hypertension are expected to be able to do deep breathing relaxation, progressive muscle relaxation and light yoga to reduce pain and anxiety. The method used in the form of counseling, training and demonstration. The results of this service from 10 elderly experienced an increase in knowledge of 90\%. Elderly who took part in this program was very enthusiastic in the practice process and in providing material. The results of the elderly pretest did not recognize pain and anxiety management, on the contrary the results of the elderly post test were able to understand and practice correctly. deep breath relaxation, progressive muscle relaxation and light yoga exercises as much as 90\%. This exercise can be done every day to reduce blood pressure, pain and anxiety.
\end{abstract}

Keywords: elderly, hypertension, deep breathing relaxation, progressive muscles, yoga

\section{PENDAHULUAN}

Hipertensi sekarang menjadi masalah utama, tidak hanya di Indonesia tapi di dunia, karena hipertensi ini merupakan salah satu pintu masuk atau faktor risiko penyakit seperti gagal ginjal, diabetes, stroke, jantung [1]. Hipertensi kerap ditemukan pada lansia dengan ciri serta indikasi yang ditemui sakit kepala pada bagian belakang kepala, leher terasa kaku, keletihan, mual, sesak nafas, risau, muntah, gampang tersinggung, sukar buat tidur serta takut.

Gejala hipertensi salah satunya nyeri pada tengkuk kepala. Nyeri yang berlarut larut ini lah yang menyebabkan penderita merasa takut sebab nyeri yang dialami hilang timbul. Penderita dengan hipertensi menampilkan indikasi kecemasan, tekanan mental serta stress [2]. Prevalensi hipertensi meningkat di banyak negara sejalan dengan perubahan gaya hidup semacam merokok, kegemukan, kegiatan fisik serta stress psikososial [3].

Kecemasan bisa ditimbulkan sebagai akibat dari tekanan darah itu sendiri, Cemas disebabkan karena khawatir apabila tekanan darah bisa melonjak tinggi yang berdampak parah untuk badan serta kelangsungan hidup, sebab sebagian pengaruh tekanan darah tinggi ini bisa 
memunculkan penyakit beresiko yang lain semacam lumpuh, jantung serta stroke yang bisa berdampak pada kematian [4]. Penelitian yang dilakukan Marliana Marliana (2019) menyampaikan kalau sebagian besar responden mengalami hipertensi sebanyak 87 orang 70 , $2 \%)$, serta sebagian besar responden yang mempunyai kecemasan ringan, sebanyak 107 orang $(86,3 \%)$ [5]. Ada hubungan antara kecemasan dengan peristiwa hipertensi (P Value $=0,041) \mathrm{di}$ Puskesmas Kecamatan Kramat Jati Tahun 2019 [5]. Penelitian yang dilakukan Idayati, (2016) terdapat hubungan antara ansietas dengan peristiwa hipertensi pada penderita rawat jalan Puskesmas Pringsewu Kabupaten Pringsewu Tahun 2016 [6].

Penatalaksanaan pada penderita hipertensi dengan keluhan nyeri serta cemas dapat dilakukan dengan tindakan non farmakologi yang bisa menolong mengatur nyeri serta takut berupa masase, relaksasi, imajinasi, pemakaian kompres panas serta dingin, sentuhan terapeutik, meditasi [7]. Latihan slow deep breathing (latihan nafas dalam) dapat menurunkan tekanan darah serta kecemasan pada penderita hipertensi [3]. Penelitian lain bahwa metode relaksasi bisa menurunkan tekanan darah baik sistolik ataupun diastolik pada penderita hipertensi [8]. Penurunan tekanan darah mempengaruhi kualitas hidup penderita hipertensi dengan berkurangnya keluhan rasa nyeri di tengkuk serta kepala, sehingga meningkatkan kemampuan mengendalikan perasaannya.

Penatalaksanaan yang lain menurunkan nyeri serta cemas ialah dilakukannya relaksasi otot progresif. Ada hubungan tekanan darah pasca diberikan relaksasi otot progresif terhadap penurunan tekanan darah sistolik serta diastolik pada penderita hipertensi [9]. Penelitian (Pujiastuti., 2019) terkait penatalaksanaan yang lain yaitu dengan dilatih dengan gerakkan yoga mampu menurunkan kecemasan serta menurunkan tekanan darah penderita hipertensi, sehingga yoga sangat disarankan buat diterapkan kepada penderita hipertensi dalam menurunkan kecemasan dan tekanan darah. Yoga dapat digunakan sebagai pengobatan alternatif bagi penderita hipertensi, sehingga dapat diaplikasikan kepada masyarakat dengan menyesuaikan olahraga secara teratur [10].

Bersumber pada latar belakang di atas menunjukkan prioritas masalah utama yang dialami mitra adalah tinndakan apa saja yang dapat meredakan nyeri serta menurunkan kecemasan yang dirasakan pada mitra yang hipertensi. Tim pelaksana pengabdian kepada warga fokus pada kegiatan keperawatan untuk menurunkan nyeri serta kecemasan dengan diberikannya relaksasi nafas dalam, latihan otot progresif serta gerakkan yoga ringan dimana ketiga kegiatan tersebut bisa meredakan nyeri serta kecemasan pada penderita hipertensi. Masalah pada Lansia dengan hipertensi yaitu lansia mengeluhkan nyeri dan mengalami kecemasan sehingga membutuhkan tindakan atau latihan untuk mengurangi masalah tersebut.

\section{METODE}

Mitra dalam kegiatan ini merupakan lansia yang mempunyai penyakit hipertensi yang berjumlah 10 orang yang memiliki keluhan nyeri di tengkuk, perih kepala, takut, susah tidur serta khawatir. Metode kegiatan ini berupa penyuluhan dan pelatihan. Kegiatan pengabdian dilaksanakan disalah satu rumah kader lanjut usia di kelurahan Beringin Ngaliya dimulai dengan penyampaian modul dengan media LCD/ proyektor. Kegiatan pengabdian warga dilaksanakan meliputi,

1. Pre test mengenai pengetahuan lansia tentang hipertensi dan penanganannya

2. Pemilihan lansia yang mengidap hipertensi bekerjasama dengan kader lansia

3. Prosedur pertama merupakan dengan memberikan penyuluhan dengan materi“ Hipertensi serta penatalaksanaan hipertensi" serta dilanjutkan dengan tahap tanya jawab.

4. Kegiatan kedua dengan memberikan penyuluhan serta pelatihan mengenai“ relaksasi nafas dalam serta relaksasi otot progresif” dalam mengatasi nyeri serta kecemasan pada penderita hipertensi. Mitra diminta mempraktikan latihan nafas dalam serta relaksasi otot progresif 
5. Kegiatan ketiga dengan memberikan penyuluhan serta pelatihan " latihan gerakkan yoga ringan untuk meringankan nyeri serta kecemasan pada penderita hipertensi". Salah satu mitra dimohon mempraktikan dengan proses tutorial.

6. Post test tentang pengetahuan hipertensi dan praktik latihan yang sudah diajarkan.

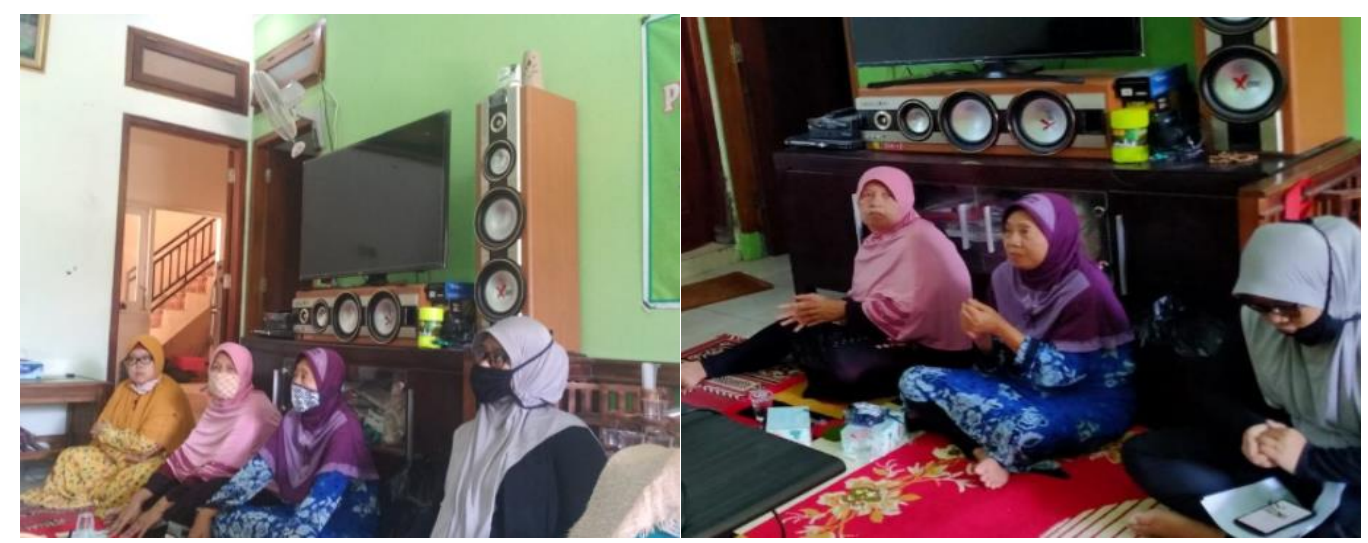

Gambar 1 Penyuluhan berupa Pemberian Materi

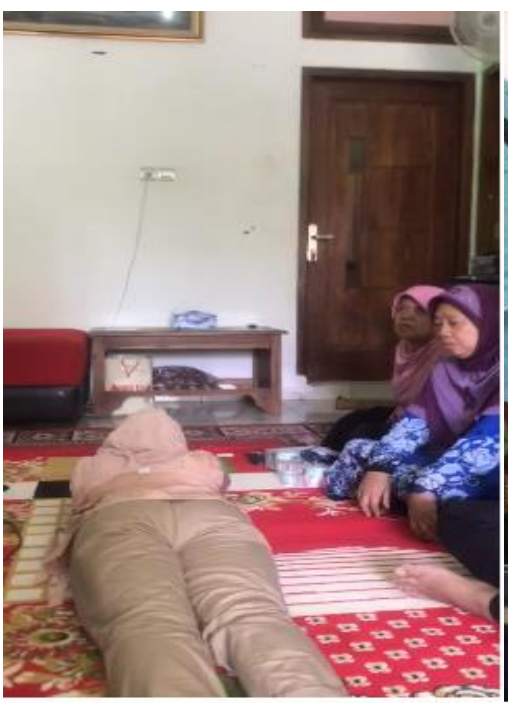

(a)

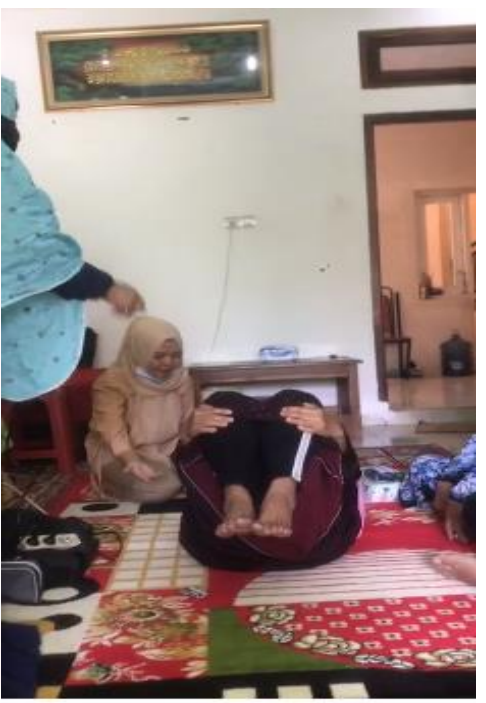

(b)

Gambar 2 Praktik Yoga Ringan Mahasiswa (a) Praktik Yoga Ringan Lansia (b)

\section{HASIL DAN PEMBAHASAN}

Kegiatan pengabdian ini diikuti dengan jumlah lansia sebanyak 10 orang dimana lansia yang terlibat adalah lansia yang masih aktif yaitu lansia yang mampu melakukan kegiatan aktifitas sehari-hari secara mandiri.

Hasil test diatas ditemukan data bahwa lansia mengalami peningkatan pengetahuan tentang hipertensi. Lansia juga mampu melakukan praktik latihan relaksasi nafas dalam, otot progresif dan gerakkan yoga ringan. Peserta mengalami hipertensi rata-rata sudah tiga tahun. Lansia selama ini bila nyeri muncul yang dilakukan yaitu hanya tiduran atau berbaring di tempat tidur saja. Nyeri yang muncul disertai dengan keluhan sulit tidur dan cemas. Hipertensi yang dirasakan telah lama akan memunculkan permasalahan kesehatan. Keluhan yang senantiasa menyertai hipertensi apabila tekanan darah seketika naik ialah nyeri pada leher sehingga memunculkan kecemasan. Muncul perasaan takut inilah yang memperberat keadaan fisik. Nyeri bisa memunculkan kecemasan demikian juga kebalikannya kecemasan bisa memperburuk nyeri sehingga toleransi seorang terhadap rendah. Tingkatan kecemasan di atas rata- rata pada penderita hipertensi ini bisa jadi diakibatkan oleh aspek non fisik ataupun aspek psikologis [4]. 


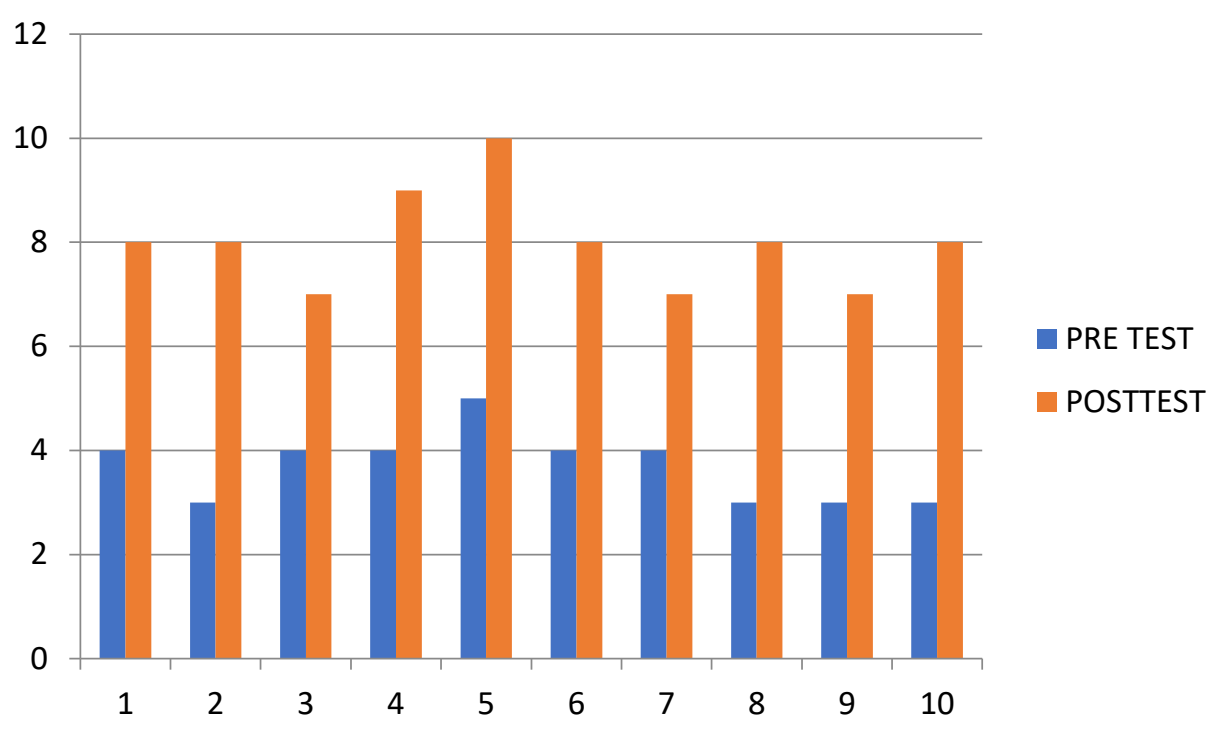

Diagram 1. Hasil Pretest dan Posttest Tingkat Pengetahuan tentang Hipertensi dan Penatalaksanaanya

Penatalaksanaan pada penderita hipertensi dengan keluhan nyeri serta cemas dapat diberikan pengobatan non farmakologi yang dapat menurunkan nyeri serta cemas meliputi masase dan relaksasi. Metode relaksasi yang digunakan adalah relaksasi nafas dalam, relaksasi otot progresif serta gerakkan yoga ringan. Relaksasi otot progresif sangat bermanfaat dalam menanggulangi bermacam penyakit, semacam tekanan darah tinggi serta migrain. Seorang dalam kondisi stres seluruh ototnya berkontraksi ataupun tegang/kaku. Inilah yang menimbulkan munculnya kelelahan serta serat otot tidak bisa berfungsi dengan baik [11]. Ketegangan otot bisa menimbulkan sakit, sakit punggung, kaku leher, sebagian berbagai sendi ataupun indikasi komplikasi yang lain [11], setelah diberikan relaksasi otot progresif, relaksasi napas dalam terdapat perubahan tekanan darah sistolik serta diastolik pada hipertensi [9]. Penelitian Pujiastuti (2019) meyakinkan kalau yoga mampu menurunkan kecemasan serta menurunkan tekanan darah penderita hipertensi. Dampak relaksasi napas, otot progresif serta yoga ringan dapat membuat penderita merasa rileks serta tenang [10]..

\section{KESIMPULAN}

Lansia dengan hipertensi bila muncul gejala nyeri dan cemas dapat melakukan kegiatan latihan nafas dalam, relaksasi otot progresif dan yoga ringan. Kegiatan ini dapat dilakukan setiap hari untuk mengurangi nyeri dan cemas.

\section{DAFTAR PUSTAKA}

[1] M. Nurman, "Efektifitas Antara Terapi Relaksasi Otot Progresif dan Teknik Relaksasi Nafas Dalam Terhadap Penurunan Tekanan Darah pada Penderita Hipertensi Di Desa Pulau Birandang Wilayah Kerja Puskesmas Kampar Timur Tahun 2017," J. Ners Uniersitas Pahlawan Tuanku Tambusai, vol. 1, no. 2, pp. 108-126, 2017, [Online]. Available: http://journal.universitaspahlawan.ac.id/index.php/ners/article/view/122.

[2] I. A. Kretchy, F. T. Owusu-Daaku, and S. A. Danquah, "Mental health in hypertension: Assessing symptoms of anxiety, depression and stress on anti-hypertensive medication adherence," Int. J. Ment. Health Syst., vol. 8, no. 1, pp. 4-9, 2014, doi: 10.1186/1752-44588-25. 
[3] T. C. Sepdianto, E. Nurachmah, and D. Gayatri, "Penurunan Tekanan Darah dan Kecemasan Melalui Latihan Slow Deep Breathing Pada Pasien Hipertensi Primer," J. Keperawatan Indones., vol. 13, no. 1, pp. 37-41, 2010, doi: 10.7454/jki.v13i1.229.

[4] F. Zahara, "Hubungan antara kecemasan dengan tekanan darah pada Penderita hipertensi di rsu pku muhammadiyah yogyakarta," Kognisi Jurnal, Vol.2 No.1 Agustus 2017 25284495, vol. 2, no. 1, pp. 42-53, 2017.

[5] T. Marliana, I. S. Kaban, and U. Chasanah, "JAKARTA TIMUR Pendahuluan Metodologi Penelitian," pp. 306-311, 2019.

[6] I. Idayati, "Tingkat Ansietas Dengan Kejadian Hipertensi Pada Pasien Rawat Jalan Di Puskesmas," J. Ilm. Kesehat., vol. 5, no. 10, pp. 724-733, 2016, doi: 10.35952/jik.v5i10.35.

[7] L. Nabila, Witri Setiawati, Mardison, "REAL in Nursing Journal ( RNJ )," Real Nurs. J., vol. 3, no. 3, pp. 84-94, 2020.

[8] I. Sulistyarini, "Terapi Relaksasi untuk Menurunkan Tekanan Darah dan Meningkatkan Kualitas Hidup Penderita Sulistyarini, I. (2013) 'Terapi Relaksasi untuk Menurunkan Tekanan Darah dan Meningkatkan Kualitas Hidup Penderita Hipertensi', Jurnal Psikologi, 40(1), pp. 28-38. A," J. Psikol., vol. 40, no. 1, pp. 28-38, 2013, [Online]. Available: https://media.neliti.com/media/publications/128922-ID-terapi-relaksasi-untukmenurunkan-tekana.pdf.

[9] Nurma, Penerapanterapi Progressive Muscle Relaxation Terhadap Tingkat Kecemasan Pada Pasien Hipertensi Karya, Med. Bedah, 2019.

[10] R. S. E. Pujiastuti, S. Sawab, and S. Z. Afiyati, "Pengaruh Terapi Yoga Terhadap Penurunan Tekanan Darah Pada Penderita Hipertensi," J. Perawat Indones., vol. 3, no. 1, p. 36, 2019, doi: 10.32584/jpi.v3i1.181.

[11] Schiavo, “No 主観的健康感を中心とした在宅高齢者における 健康関連指標に関する共 分散構造分析Title,” vol. 02, no. 01, pp. 1-20, 2014. 